\title{
THE EUROPEAN EXPERIENCE: THE EUROPEAN CONVENTION ON HUMAN RIGHTS
}

\author{
Kevin Boyle*
}

This article focuses on the European Convention on Human Rights and its Court of Human Rights. It explains the relationship between the Council of Europe, the Convention, and the Court as a system that is also a working example of a regional human rights mechanism. Some important rights and freedoms affirmed under the Convention are detailed, as is the impact of the Court's decisions on other judicial bodies. The article also comments on some future challenges for the Court.

\section{INTRODUCTION}

This article centres on the European Convention on Human Rights (ECHR) ${ }^{1}$ and its Court of Human Rights ("the Court"). There are three intergovernmental structures in European with human rights protection dimensions. They are:

(1) The Organisation of Security and Co-operation in Europe (OSCE) created in Helsinki in 1975 and embracing 55 states (including the United States and Canada), with headquarters at Vienna and Warsaw;

(2) The European Union, created originally in 1953 and now with 27 member states, with headquarters in Brussels; and

(3) The Council of Europe created in 1949 now 47 states under which the ECHR operates, with headquarters at Strasbourg.

This article explains the relationship between the Council of Europe, the ECHR and the Court. Key rights and freedoms protected under the ECHR and the individual complaints procedure are

* Professor of Law, Human Rights Centre, University of Essex, United Kingdom.

1 European Convention for the Protection of Human Rights and Fundamental Freedoms (4 November 1950) 213 UNTS 221 [ECHR] 
detailed. The article discusses the impact of the Court's decisions on other judicial bodies and finally comments on some future challenges for the Court.

\section{THE COUNCIL OF EUROPE}

The ECHR and its Court were recently described by one of its senior registrars thus: ${ }^{2}$

There seems to be unanimous agreement in Europe today that the European Convention on Human Rights (ECHR) is one of the major developments in European legal history and the crowning achievement of the Council of Europe.

The ECHR extends to some 800 million people in 47 states. It provides the right for people to bring complaints outside their state that their Government has violated the rights and freedoms guaranteed under its provisions. An independent court rules on such complaints. All state parties are bound under the ECHR to implement the judgments of the Court. The Court, where it finds a violation, awards "just satisfaction" to the individual applicant. This is normally financial compensation, but its judgment may also require that laws and practices be changed. Before discussing the crowning achievement of a regional human rights court, this paper will focus on the Council of Europe itself.

Without the creation of this inter-governmental body in 1949 there would be no ECHR or Court, nor would the extraordinary achievements of the Court in protecting human rights of individuals in Europe have come about. In the context of the Pacific region it is important to underline that a regional human rights mechanism needs to have the co-operation of states and an intergovernmental institution within which the mechanism operates. What above all is needed is the political will of states to agree to such a mechanism, to fund it and to implement its decisions or recommendations.

Debate over regionalism versus universal systems of human rights protection have noted that regional arrangements are the more likely to succeed if the states and their peoples have a wider agenda of co-operation that includes but is not confined to human rights, and that there is some clear purpose inducing them to cooperate more widely and to construct institutions to deliver that cooperation. The United Nations High Commissioner for Human Rights made that point recently in respect of developments in Association of Southeast Asian Nations (ASEAN): ${ }^{3}$

I believe that an ASEAN Human Rights Mechanism can articulate a common approach to a complex problem, an approach that will assist ASEAN Member States, from a position of shared regional values, to address shortcomings in their national frameworks so as to allow individuals the means to enjoy their

2 Michael Boyle "On Reforming the Operation of the European Court of Human Rights" [2008] EHRLR 1.

3 Presentation by United Nations High Commissioner for Human Rights, $14^{\text {th }}$ Annual Workshop of the Framework on Regional Co-operation for the Promotion and Protection of Human Rights in the AsiaPacific Region (Bali, Indonesia, 10-12 July 2007). 
rights in full, and to obtain effective redress when those rights are denied. An ASEAN human rights mechanism can also assist ASEAN governments to better address regional human rights concerns related to organised crime, terrorism, human trafficking, sexual exploitation of migrant workers and children, as well as environmental concerns which have human rights implications. Finally, I believe that an ASEAN human rights mechanism will serve as an inspiration and model for further progress within the other sub-regions of this broad and diverse Asia-Pacific region.

In the European case, as with the African regional system, the main driver was greater political integration or union between states. The history of the Council of Europe certainly confirms this: it was created in 1949 by the Treaty of London after the Second World War and in the aftermath of the Nazi regime. That experience was one major impetus to create trans-national institutions for human rights protection. Another was the polarisation in Europe between the USSR and Western states with the division of Germany and the communist takeover of East European countries such as Poland and Hungary. Thus there was the need for Western states to come together to define themselves and their values in opposition to their own past and the Communist East.

The key institutions of the Council of Europe are a Committee of Ministers (CoM) and a Parliamentary Assembly (PACE). CoM is an inter-governmental body that meets at the level of foreign ministers or their permanent deputies in its seat at Strasbourg. PACE is an indirectly elected body in that it involves Parliamentarians already elected to their national Parliaments and nominated. Both bodies are deeply involved in the functioning of the ECHR. PACE elects the judges of the Court, and CoM is given responsibility to supervise the execution of judgments of the Court created under the ECHR. In summary, in discussing Europe we should think of a system of regional human rights protection established under the Council of Europe within which the ECHR and the Court are the jewels in the crown. ${ }^{4}$

\section{THE EUROPEAN CONVENTION ON HUMAN RIGHTS}

The ECHR was agreed in 1950 and came into force in 1953, initially with only 10 Western European member states. It gradually expanded membership until all Western and Southern European states were members. By 1990 with the accession of Finland there were 24 member states. Between 1990-2007, the number of states doubled as Eastern European countries joined, including the largest state in Europe: Russia. The Republic of Montenegro became the forty-seventh member of the Council of Europe on 11 May 2007. The forty-eighth no doubt at some point will be Kosovo. That leaves Belarus as the sole non-member state in Europe. All member states are required to ratify the ECHR and a range of other instruments.

4 For further detail on the Council of Europe and its institutions see the official website www.coe.int. 


\section{A Rights and Freedoms Protected}

The ECHR creates a regional system of judicial protection for civil and political rights drawn from the Universal Declaration of Human Rights (UDHR). Note the Preamble: ${ }^{5}$

Being resolved, as the governments of European countries which are like minded and have a common heritage of political traditions, ideals, freedom and the rule of law, to take the first steps for the collective enforcement of certain of the rights stated in the Universal Declaration...

Thus there is no such thing as a "European human right," but universal rights. There is rather a "European" system of protection of these rights. The ideological polarisation of the time between East and West finds reflection in the division between civil/political, and economic, social and cultural rights. The parallel convention for the latter categories of rights is the European Social Charter, which has its own collective complaint mechanism as well as machinery for adjudication and enforcement.

The rights guaranteed in the ECHR are contained in section 1 and its Protocols, and cover classic civil and political rights including the right to life, freedom from torture, liberty, fair trial, right to private and family life, property and possessions, freedom of thought and religion expression and association. In recent years the importance of non-discrimination and equality rights has been recognised both in important cases especially in respect of the Roma minority ${ }^{6}$ but also through a new Protocol in force since 2004 which established an independent equality duty on states. $^{7}$

\section{B The Institutions Established by the ECHR}

As was first agreed, the ECHR established a Commission of Human Rights ("the Commission"). This quasi-judicial body examined the admissibility of applications claiming violation of rights under the ECHR as well as the Court. This body was abolished in the reforms introduced by Protocol Number $11,{ }^{8}$ which replaced the Commission and the former part-time court by the fulltime court. The Commission's members, the same as the number of states that ratified the ECHR, sat in their individual capacities and were independent of their governments. The Commission held hearings and made decisions on the admissibility of complaints as well as giving its opinion on the merits of any complaint. The final legal decision as to whether there was a violation of the ECHR

5 Universal Declaration of Human Rights 1998 UNGA Res 217 (III), UN Doc A/810 71.

$6 \quad$ DH v The Czech Republic (2007) 23 435-600 BHRC 526 (Ground Chamber ECHR). Application no 57325/00 Judgment (14 November 2007). This case held that segregating Roma students into special schools was a form of unlawful discrimination in breach of Art 14 of the ECHR (prohibiting discrimination), taken together with Protocol No 1 art 2 (securing the right to education).

7 ECHR Protocol No 12 ETS 117 (4 November 2000).

8 ECHR Protocol No 11 ETS 155 (1 November 1998). 
was reserved to the Court or, if the case was not sent there, then the legal determination was in fact made by an non-judicial body, the Committee of Ministers. This structure was the model followed with variations by the Inter-American and African regional systems. There may be merit in discussing whether the model of a quasi-judicial Commission might have value for any Pacific regional mechanism.

Meanwhile, for a variety of reasons but principally because of the expansion of membership, greater awareness of the ECHR and the huge increase in the volume of applications, the European system has been in a period of virtually continuing reform since the 1990s. The question of further reform and the current crisis caused by the workload of the Court is discussed further below.

\section{Complaint Procedures}

The ECHR provides for both inter-state and individual complaint procedures. The original thinking was that states would be the guardians of the ordre public of Europe and bring before the ECHR control bodies other states whose activities within their jurisdictions violated human rights. However, it has not worked out like that. There have been very few inter-state complaints over the ECHR's more than fifty-year history. Rather it has been the individual complaint mechanism that has been the driver of the ECHR and is responsible for its astonishingly broad and rich jurisprudence on ECHR rights and freedoms.

1 Key provisions in the ECHR relevant to the complaint mechanism

Article 1 - Obligation to respect human rights

The High Contracting Parties shall secure to everyone within their jurisdiction the rights and freedoms defined in Section I of this Convention.

Article 34 - Individual applications

The Court may receive applications from any person, non-governmental organisation or group of individuals claiming to be the victim of a violation by one of the High Contracting Parties of the rights set forth in the Convention or the protocols thereto. The High Contracting Parties undertake not to hinder in any way the effective exercise of this right.

Article 35 - Admissibility criteria

The Court may only deal with the matter after all domestic remedies have been exhausted, according to the generally recognised rules of international law, and within a period of six months from the date on which the final decision was taken. 
The Court shall not deal with any application submitted under Article 34 that:

is anonymous; or

is substantially the same as a matter that has already been examined by the Court or has already been submitted to another procedure of international investigation or settlement and contains no relevant new information.

The Court shall declare inadmissible any individual application submitted under Article 34 which it considers incompatible with the provisions of the Convention or the protocols thereto, manifestly illfounded, or an abuse of the right of application.

The Court shall reject any application which it considers inadmissible under this Article. It may do so at any stage of the proceedings.

Article 13 - Right to an effective remedy

Everyone whose rights and freedoms as set forth in this Convention are violated shall have an effective remedy before a national authority notwithstanding that the violation has been committed by persons acting in an official capacity.

\section{Victims and jurisdiction}

Article 1 underscores that it is the duty of a state which ratifies to ensure protection of the human rights of everyone in the jurisdiction - not only of nationals. However, to complain of a violation under Article 34 the person must be a victim. There has developed over the years a considerable jurisprudence as to the meaning of both "within the jurisdiction" and "victim". The indirect reach of the ECHR is best illustrated by Soering $v$ United Kingdom. ${ }^{9}$ In that case, the Court held that the threatened extradition of a German national from Britain to face a capital murder charge in the United States would violate, on the United Kingdom's part, the ECHR's prohibition against inhumane or degrading treatment, because of the applicant's exposure to the "death row phenomenon". On similar reasoning, the Court has applied the ECHR to protect refugees and asylum-seekers from being deported to countries where they may face torture. ${ }^{10}$

Direct and indirect victims may maintain an application; the latter are generally relatives or others with a close connection to the victim, who may be deceased or a minor. The ECHR's organs to date have been liberal in interpreting standing, but the Court will not entertain an in abstracto application or an actio popularis which alleges general human rights violations unconnected to any specific victim applicant.

$9 \quad$ Soering v United Kingdom Application No 14038/88 ECHR (1989) 11 EHRR 439 Series A No 161.

10 Chahal v United Kingdom Application No 70/1995/576/662 (1996) ECHR Series A No 697, later confirmed in Saadi v Italy Application No 37201/06 ECHR (28 February 2008). 


\section{Exhaustion of local remedies}

The key article of the ECHR is Article 34, which governs conditions of admissibility. Out of every 100 applications to the Court, 90 are rejected under the heading of failure to meet one or more of the admissibility criteria required in Article 34. The most frequent ground for rejection is the failure to exhaust domestic or internal remedies. The domestic remedies rule reinforces a fundamental element of any international complaint procedure; namely, that the state accused must have had the opportunity to address the grievance domestically before it can be made to answer it in an international court or other forum. The Court frequently emphasises that its role is subsidiary to the national protection system. It is only when the individual has exhausted domestic remedies or such remedies are inadequate and ineffective that the case can be examined at the ECHR level. There is, as might expected, a substantial body of ECHR case law that has considered what constitutes inadequate or ineffective remedies and when an applicant can be said to have exhausted them.

\section{Right to a remedy}

The right to an effective remedy under Article 13 above is closely related to the question of exhaustion of domestic remedies. If there is no effective remedy that can allow an application to be admitted while at the same time finding for the applicant over their substantive complaint, the lack of a remedy might lead to a violation of Article 13. Frequent examples arise over complaints regarding the use of deadly force by police or ill treatment in custody. The Court has often found in addition to violation of the right to life or torture (Articles 2 and 3, respectively) that Article 13 has been violated because there was no procedure for complaint or effective investigation within the country.

\section{Languages}

The official languages of the Court are French and English. The rules provide that all stages of an application prior to admissibility, including correspondence, can be conducted in either English or French or an official language of the contracting parties. After admissibility, written pleadings and oral hearings must be in English or French.

\section{Legal representation and legal aid}

Individuals and organisations may initially file applications to the Court without legal representation. In further stages of the proceedings, however, a lawyer must represent an applicant, unless the President of the Chamber decides otherwise. An applicant may appoint any advocate authorised to practice in any member state of the Council of Europe or other approved representative.

One of the most innovative and, in practical terms, most important features of the ECHR is its provision for legal aid in individual applications. The assistance is paid from Council of Europe 
funds and governed by the Court's Rules. The Court may grant legal aid either on the request of the applicant or on its own initiative.

\section{THE IMPACT OF THE ECHR}

The impact of what is now some half a century of jurisprudence of the Court of the ECHR at national level has been undoubtedly profound. The ECHR and the judgments of the Court have deeply influenced the legal orders of all its member states. The ECHR is now incorporated in the legal systems of member states. National courts including constitutional courts have, over time, come to embrace and absorb the Court's judgments on human rights. The existence of an internationally located judicial review of legislation has influenced the growth of domestic judicial review; a jurisdiction not strongly developed in many countries' legal traditions when the ECHR was first drafted. There is a level of trust established between national governments and the ECHR organs that is unique in the world.

The ECHR and Court have had a major influence particularly in the transformation of the principles of the rule of law democracy and human rights in the former Communist states of Eastern Europe over the last fifteen years. It has been said that in the long view of history the greatest achievement of the ECHR may be to have existed post-1990 and the fall of the Berlin Wall. One might add that beyond Europe its judgments have had influence in many national courts when interpreting bills of rights, as well as in other regional and United Nations human rights bodies. ${ }^{11}$

Over the years the ECHR, the Court and the former Commission on Human Rights have also had to respond to instability and widespread internal conflict in some member states from the Northern Ireland emergency, southeast Turkey and Chechnya. It might be thought that such situations of gross or widespread violations of human rights are not well suited for the intervention of an international court. However, through the invocation of the individual complaint procedure, the Strasbourg mechanism did make a difference to thousands of victims of torture, arbitrary killings, disappearances and internal displacement.

Apart from justice to the individual applicants or their next of kin, the case law of the Court provides a diagnosis of what went wrong and what needed change in the national legal system to protect human rights. The space was thereby created to address the structural changes needed to implement the judgments of the Court; this is a role that the Committee of Ministers plays under the ECHR. The judgments of the Court also enable civil society to follow up and press for reform or justice on the ground. In conflict situations such as Turkey or Chechnya more of course is needed if gross violations of human rights are to end. Nevertheless, the reputation of the Court is such that its judgments, when exposing major violations of human rights, have a powerful influence on political actors as well as on European opinion as a whole.

11 Boyle, above n 2. 
As is frequently said, the major challenge to the Court is that it is a victim of its own success. It is literally drowning under its caseload. Despite now sitting in five chambers continuously and delivering hundreds of judgments per year, as at September 2007 it had 103,600 cases pending. ${ }^{12}$ Four countries between them account for half of these: Russia, Ukraine, Turkey and Romania. There are two responses to this impossible caseload. The Court has made many efficiency efforts and has tried to prioritise more serious cases as well as experiment with so-called "pilot judgments" to address repetitive applications. ${ }^{13}$ It has also sought to press member states to do more to address complaints domestically, for example, by ensuring that all new draft legislation as well as existing law and administrative procedures are reviewed so as to be compatible with the ECHR and corresponding case law.

The second response is to move away from the practice that the Court should consider all applications submitted and rule on them in favour of a power to select cases. That idea is part of a new Protocol Number 14, ratified by all states except Russia and thus it may never come into force. According to some, if the Court is to survive it needs to effectively become a constitutional court that concerns itself with principles and set pan-European standards on human rights, rather than be, as it has been put, a "small claims court" for the whole of Europe. Those who argue that its legitimacy rests with the individual applicant and his/her right to engage the Court to seek relief resist this. Non-governmental organisations, human rights defenders and many lawyers tend to favour the status quo. There is no obvious resolution to the Court's difficulties on the horizon. These are problems of course of a very different nature to what is of concern to the Pacific region.

12 www.echr.coe.int/ECHR/EN/Header/Reports+and+Statistics/Statistics/Statistical+information+by+year.

13 See Broniowski v Poland (2005) 40 EHRR 495 (Grand Chamber, ECHR). 
